... Öz, Deniz, Okan, Fidan: Chemical Composition of Oleoresin and Larvae Gallery Resin...

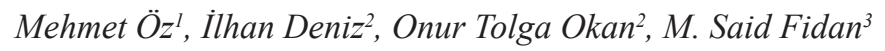

\title{
Chemical Composition of Oleoresin and Larvae Gallery Resin of Pinus Brutia Attacked by Dioryctria Sylvestrella Ratz.
}

\section{Kemijski sastav oleorezina i smole galerije ličinki sa stabla bora (Pinus brutia) napadnutoga insektima Dioryctria sylvestrella Ratz.}

Original scientific paper • Izvorni znanstveni rad

Received-prispjelo: 27. 2. 2014.

Accepted-prihvaćeno: 20. 5. 2015.

UDK: $630 * 813.26 ; 630 * 813.27 ; 674.032 .475 .4$

doi:10.5552/drind.2015.1408

\begin{abstract}
Dioryctria sylvestrella Ratz. poses a remarkable hazard for the Pinus brutia Ten. in Turkey. In the current study, the larvae gallery resin of five trees and essential oils of resin, which was obtained with the AcidPaste Method, were analyzed using the Gas Chromatography and Mass Spectrometry (GC-MS) Method. Thirty nine compounds were found in larvae gallery resin, which were produced by Dioryctria sylvestrella Ratz, while thirty six compounds were extracted from oleoresin obtained by the Acid-Paste Method. The most common compounds of larvae gallery resin were $\alpha$-pinene at a rate of $20.2 \%, \beta$-caryophyllen at a rate of $10.8 \%$, $\gamma$-terpinene at a rate of $10.1 \%$ and $\beta$-pinene at a rate of 9.4 percent. The most common compounds of oleoresin were $\alpha$-pinene at a rate of $19.7 \%$, $\beta$-pinene at a rate of $13.3 \%, \gamma$-terpinene at a rate of $10.2 \%$ and $\beta$-caryophyllen at a rate of 7.8 percent. Also, the quantities of some compounds within larvae gallery resin such as $\beta$-pinene, limonene, and sylvestrene decreased compared to those of oleoresin, while the quantities of some compounds in oleoresin including $\alpha$-longipinene, $\alpha$-terpineol, and longifolene increased compared to that of larvae gallery resin. However, no qualitative difference was found.
\end{abstract}

Key words: Acid-Paste Method, Dioryctria sylvestrella Ratz, Larvae gallery resin, Oleoresin, Pinus brutia

SAŽETAK • Insekti Dioryctria sylvestrella Ratz. izuzetno su opasni za drvo bora (Pinus brutia Ten.) u Turskoj. U provedenom su istraživanju, primjenom metode plinske kromatografije i masene spektrometrije (GC-MS), analizirane smola galerije ličinki s pet stabala i eterična ulja smole (oleorezin) dobivene metodom acid-paste. U smoli

\footnotetext{
${ }^{1}$ Author is lecturer at Gumushane University, Vocational School of Higher Education, Department of Forestry, Gumushane, Turkey. ${ }^{2}$ Authors are professor and research assistant at Karadenız Technical University, Faculty of Forestry, Department of Forest Industry Engineering, Trabzon, Turkey. ${ }^{3}$ Author is assistant professor at Gumushane University, Science and Technology Institute, Forestry and Environmental Sciences, Gumushane, Turkey.

${ }^{1}$ Autor je nastavnik Sveučilišta u Gumushaneu, Strukovna škola visokog obrazovanja, Šumarski odjel, Gumushane, Turska. ${ }^{2}$ Autori su profesor i znanstveni asistent Tehničkog sveučilišta u Karadenızu, Šumarski fakultet, Odsjek za inženjerstvo šumskih proizvoda, Trabzon, Turska.

${ }^{3}$ Autor je docent Sveučilišta u Gumushaneu, Institut znanosti i tehnologije, Šumarske i prirodne znanosti, Gumushane, Turska.
} 
galerije ličinki, nastaloj zbog napada stabala insektima Dioryctria sylvestrella Ratz., nalazi se 39 spojeva, a 36 njih ekstrahirano je iz eteričnih ulja smole (oleorezina) dobivenih postupkom acid-paste. Najčešći spojevi u smoli jesu $\alpha$-pinen kojega ima 20,2\%, $\beta$-kariofilen, s udjelom od 10,8\%, $\gamma$-terpinen, s koncentracijom od 10,1\% $i$ $\beta$-pinen, s koncentracijom od 9,4\%. Najčešći spojevi u oleorezinu jesu $\alpha$-pinen, kojega je 19,7\%, $\beta$-pinen, s koncentracijom 13,3\%, $\gamma$-terpinen, s koncentracijom 10,2\% i $\beta$-kariofilen, s koncentracijom 7,8\%. Također, količina pojedinih spojeva u smoli poput $\beta$-pinena, limonena i silvestrena manja je od količine u oleorezinu, a količine pojedinih spojeva u oleorezinu, uključujući $\alpha$-longipinene, $\alpha$-terpeniol i longifolene, povećane su u usporedbi s količinama u smoli. Međutim, nije pronađena kvalitativna razlika.

Ključne riječi: metoda acid-paste, Dioryctria sylvestrella Ratz., smola galerije ličinki, oleorezin, Pinus brutia

\section{INTRODUCTION \\ 1. UVOD}

Recently, natural herbal products have been used as raw materials in hundreds of industrial products. The natural resin is the inclusive term used to denote the products obtained from the oleoresin of pine trees. Oleoresin is obtained by the tapping of living pine trees. Collection of the oleoresin is a labour-intensive operation (Coppen and Hone, 1995). The oleoresin has a significant share in global trade of raw material. Turkey has sustainable resources throughout the country such as numerous pine trees, which can be used for the manufacturing of natural resin. The Pinus family is represented by five species in Turkey. These are Pinus nigra (Black pine), Pinus brutia (Turkish pine), Pinus sylvestris (Scotch pine), Pinus halepensis (Aleppo pine) and Pinus pinea (Stone pine) (Sezik et al., 2010). Among them, Turkish pine (Pinus brutia) is a rapidly growing species spreading over the Aegean, Mediterranean and Marmara regions, although they are infrequent along the coastal line of the West Black Sea region with an area of three million hectares, covering $14.5 \%$ of Turkish forest area (Fig. 1) (Şensöz, 2003; Kanat et al., 2004; Tümen et al., 2010).

In addition to the critical role in the eco-system (Bonello et al., 2006), Pinus brutia has a significant economic role. The wood, bark and cones of Pinus brutia, in addition to resin, are raw materials with economic value (Dığrak et al., 1999). However, amongst all raw materials, oleoresin is a non-wood forest product, which has not lost importance or value since ancient times. Recently, oleoresin has been used as the raw material in adhesive, paper, printing ink, detergent, disinfectant, perfume and throughout the paint industry (Wang et al., 2006). Various methods have been developed to extract natural oleoresin. These are open wound methods and close wound method. The open wound methods are Line Method, Big Wound Method and Acid-Paste Method, while the close wound method is Carve Hole Method (Deniz, 2002). A well-recognised method is the Acid-Paste Method. The AcidPpaste Method is less wasteful and less hazardous for use than other methods. The paste has the advantage of requiring slightly less frequent applications. The greater penetration of the paste requires the removal of a bigger strip of bark but also fewer visits to the tree (Coppen and Hone, 1995). Also, the Acid-Paste Method causes minimal damage to the tree, wood and resin components (Batur et al., 2008).

The compounds of oleoresin consist of turpentine (monoterpenes (C10), sesquiterpenes (C15)), less volatile terpenoids (diterpen resin acids (C20)) and derivatives (Trapp and Croteau, 2001; Mumm et al., 2004). The chemical composition of oleoresin is dynamic and can change with the type of environmental stress to

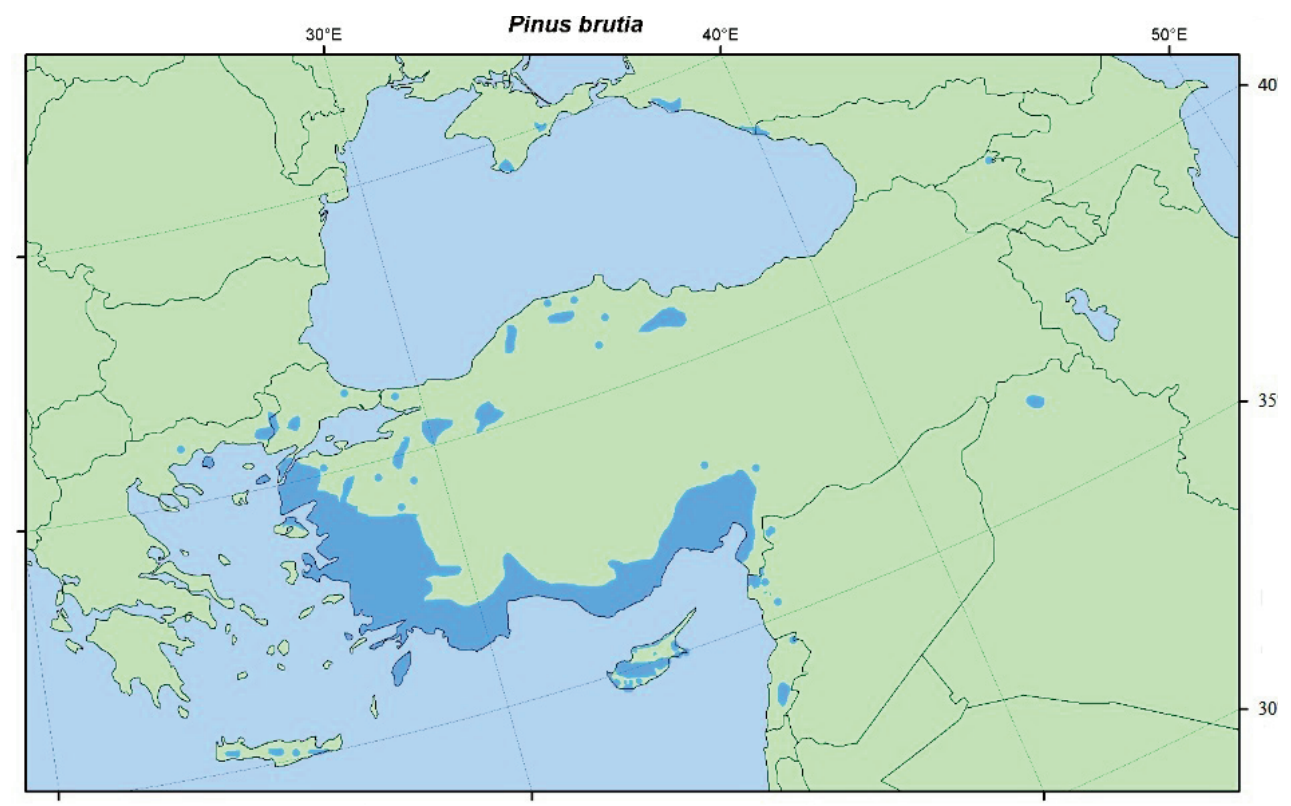

Figure 1 Natural distribution of Pinus brutia

Slika 1. Prirodna rasprostranjenost vrste Pinus brutia 

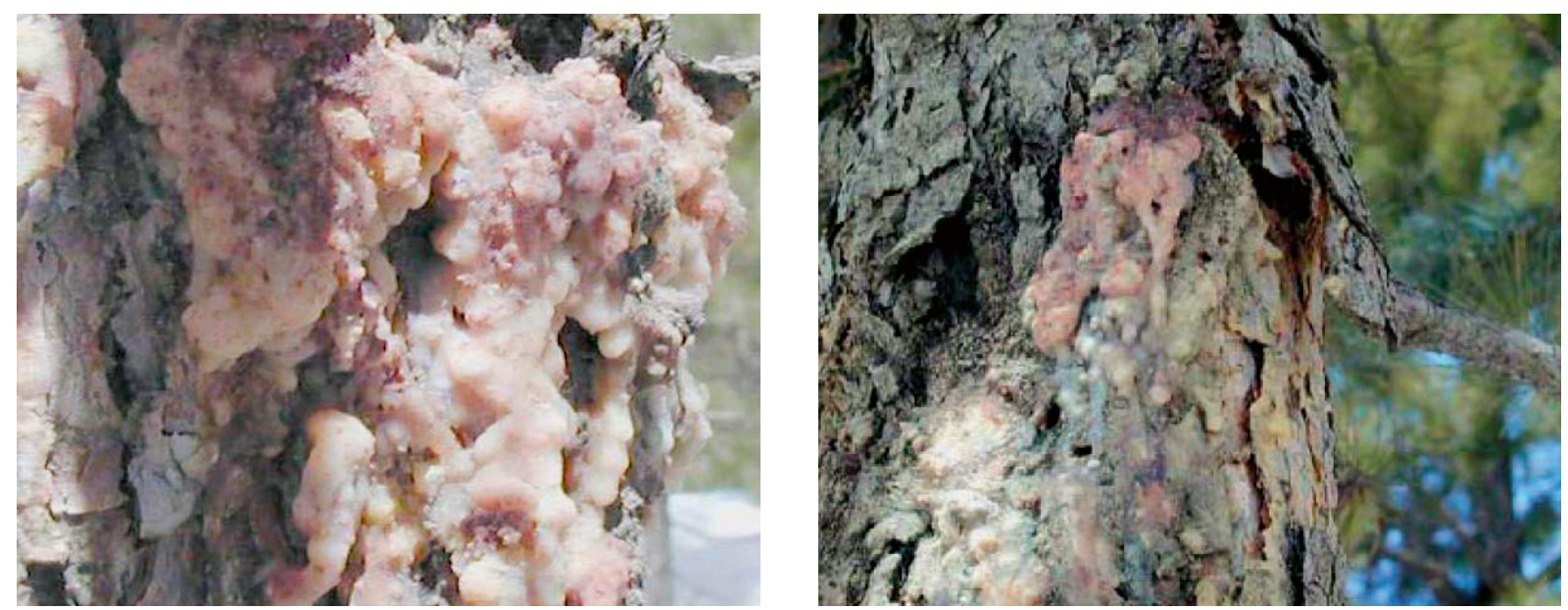

Figure 2 Discharge of larvae gallery resin after Pinus nigra was wounded by Dioryctria sylvestrella

Slika 2. Uklanjanje smole galerije ličinki s drva bora (Pinus nigra) napadnutoga insektima Dioryctria sylvestrella

which the tree is exposed (Zulak and Bohlmann, 2010). Monoterpenes and sesquiterpenes are a type of biochemical label of tree genetics. In addition, terpenes have a significant impact on the behaviour of some types of insects, such as Diocryctria (Kleinhentz et al., 1999). Dioryctria sylvestrella is one of most prominent insects that cause significant damage to coniferous tress in the forest eco-system of Turkey (Anonymos-1, 2013).

In contrast to other species of Dioryctria, Dioryctria sylvestrella does not cause conical or channel-like damage to the tree. It primarily attacks the main stem and sometimes the branches. Through the bark, the hatched larvae enter into the phloem, where they spend the winter. Larvae peel tree barks, resulting in the discharge of resin (Kleinhentz et al., 1999) (Fig. 2). Many studies have reported that many trees under attack from insects change the resin components qualitatively or quantitatively because they affect the behaviour of a variety of insects and may act as attractants or defenses (Paine et al., 1997; De Moraes et al., 1998; Kleinhentz et al., 1999; Mumm et al., 2003). A similar case is valid for trees attacked by Dioryctria sylvestrella Ratz.

Several limited studies were conducted to determine the effect of Dioryctria sylvestrella on the oleoresin chemical composition. Jactel et al. (1996) found that Maritime pine attacked by Dioryctria sylvestrella contained a significantly higher percentage of limonene, longipinene and copaene, and a discriminant analysis, using the relative percentage of six terpenes, significantly separated infested and uninfested trees. Kleinhentz et al. (1999) investigated the terpene composition of the resin between attacked and unattacked maritime pine by Dioryctria sylvestrella. They observed no significant quantitative or qualitative difference between Dioryctria sylvestrella trees that were attacked and unattacked. However, some differences in terpene proportions (semiquantiative) were significant. Sadof and Grant (1997) studied monoterpene composition of Pinus sylvestris varieties wounded by Dioryctria zimmermani. They observed that the presence of wounds had no significant effect on the proportion of monoterpenes in the four varieties. In contrast, monoterpene composition varied significantly among varieties. The above studies deal with chemical composition of oleoresin in trees attacked by Dioryctria sylvestrella. These studies are generally about chemical composition of essential oil Pinus sylvestris and Pinus pinaster wounded by Dioryctria sylvestrella. However, there is no information about chemical composition of essential oil Pinus brutia oleoresin attacked by Dioryctria sylvestrella. Therefore, the main aim of this study is to compare chemical composition of essential oil obtained from oleoresin of Pinus brutia wounded by Dioryctria sylvestrella and acid-paste tapping oleoresin.

\section{MATERIALS AND METHODS 2. MATERIJAL I METODE}

\subsection{Study field}

2.1. Područje istraživanja

Samples were taken from Findiklı Village $\left(37^{\circ}\right.$ $30^{\circ} 9 \mathrm{~N}$ and $34^{\circ} 55^{\prime} 35 \mathrm{E}$ ) of Pozantı district, Adana. Five infested Pinus brutia trees were randomly selected. The sample trees were aged 12, 20, 25, 35 and 38 years, and they were $8,13,18,15$ and 18 meters in height and 18,20,22, 30 and $35 \mathrm{~cm}$ in diameter. The Mediterranean climate is dominant in the region and the mean air temperature is $28.2^{\circ} \mathrm{C}$.

\subsection{Preparing and collecting samples}

2.2. Priprema i skupljanje uzoraka

Oleoresin and larvae gallery resin samples were taken from the same tree. Oleoresin samples were collected $1 \mathrm{~m}$ above ground level using Acid-Paste Method. The acid-paste was supplied by DYO INC. A sampling method was used to collect sufficient oleoresin. A horizontal strip of bark, $8 \mathrm{~cm}$ in width and $3.5-4 \mathrm{~cm}$ in height, was removed using wounding apparatus from the stem of the Pinus brutia. Then, the gutter was placed just below the wound to cause the oleoresin and the chemical stimulant to flow (Fig. 3). The acid-paste used as chemical stimulant was applied from $50 \mathrm{~cm}^{3}$ plastic syringes. Acid-paste consisted of $65 \%$ solution of sulphuric acid and coal, dust, barley and rice bran, dyotamide soil. Following this application, resins were 

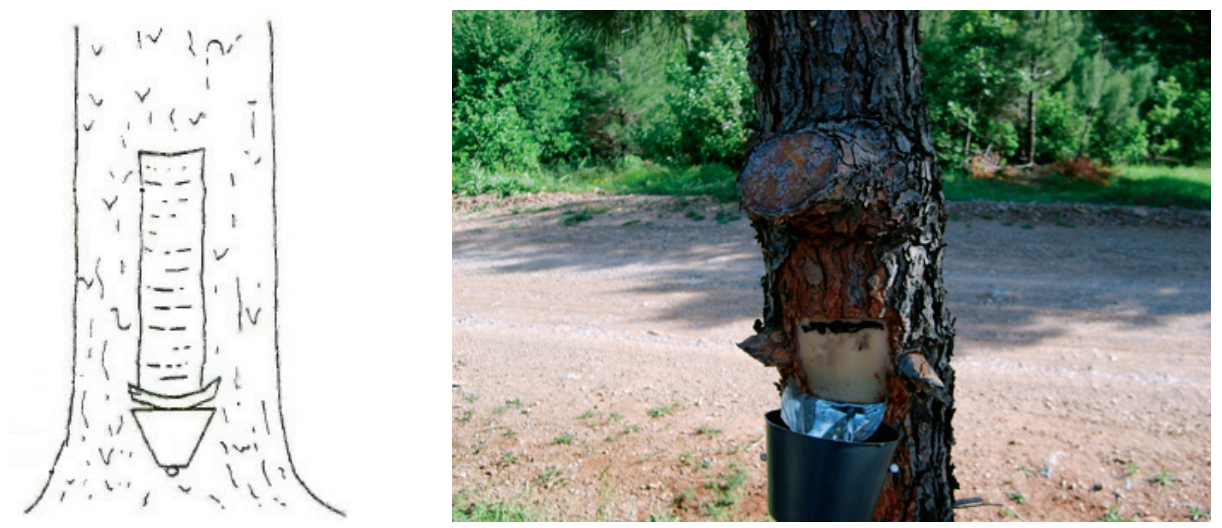

Figure 3 System of oleoresin tapping using the Acid-Paste Method Slika 3. Sustav prikupljanja oleorezina acid-paste metodom

collected from the oleoresin receiver three weeks later, in June. Resins were stored at $0{ }^{\circ} \mathrm{C}$ until analysis.

Larvae gallery resins of Pinus brutia wounded by Dioryctria sylvestrella Ratz were collected from bark cracks at $15-20 \mathrm{~cm}$ above ground in May. Fresh samples of these larvae gallery resin were selected.

\subsection{Extraction of essential oils and analysis 2.3. Ekstrakcija eteričnih ulja i analiza}

Essential oils were extracted by hydro distillation of fresh larvae gallery resin and oleoresin using a Clevenger-type apparatus for $4 \mathrm{~h}$. Resins were obtained from larvae gallery at the weight of 21.7, 21.4, 21.8, 21.6 and $21.5 \mathrm{~g}$, while oleoresins were collected using the Acid-Paste Method at the weight of 5.6, 6.5, 5.8, 20.7 and $7.5 \mathrm{~g}$, since poor raw material was released. All samples were separately transferred to a volumetric flask. Samples were ground into small pieces and distilled water $(300 \mathrm{ml})$ was added to fully immerse the samples into the volumetric flask. Clevenger type apparatus was connected to a cooling bath, which was adjusted to $-18^{\circ} \mathrm{C}$ for $4 \mathrm{~h}$. The obtained oils were dissolved in n-hexane $0.5 \mathrm{ml}$ (HPLC Grade) and dried over anhydrous sodium sulfate. The dissolved samples were stored in amber coloured bottles, which were tightly closed with paraffin applied caps, at $4{ }^{\circ} \mathrm{C}$ until analysis. The density was determined using a numeric densimeter. The following formula was used to calculate $\%$ turpentine and $\%$ rosin (1).

$$
\% A=\frac{E}{W} x 100 \text { and } \% C=100-A
$$

Where $A$ is the turpentine content (\%), $E$ is the essential oil content (g), $W$ is the sample weight (g), $C$ is the rosin content (\%).

The capillary GC-FID analysis was performed using Agilent-5973 Network System, equipped with a FID (supplied with air and hydrogen of high purity) and a split inlet. The chromatographic column for analysis was an HP-5 capillary column ( $30 \mathrm{~m} \times 0.32 \mathrm{~mm}$ i.d., film thickness $0.25 \mu \mathrm{m}$ ). Helium was used as the carrier gas at a flow rate of $1 \mathrm{~mL} / \mathrm{min}$. The injection was performed in splitless mode at $230{ }^{\circ} \mathrm{C}$. Essential oil solution $(1 \mu \mathrm{L})$ in hexane (HPLC Grade) was injected and analyzed with the column held initially at 60
${ }^{\circ} \mathrm{C}$ for 2 min and then increased to $260{ }^{\circ} \mathrm{C}$ with a $3{ }^{\circ} \mathrm{C} /$ min heating ramp. The sample was analyzed twice and the percentage constituents of oils were computed from the GC peak areas without using correction factors. GC-MS analysis was performed using Agilent-5973 Network System. A mass spectrometer with a ion trap detector in full scan under electron impact ionization $(70 \mathrm{eV})$ was used. The chromatographic column for the analysis was an HP-5 capillary column $(30 \mathrm{~m} \times 0.32$ $\mathrm{mm}$ i.d., film thickness $0.25 \mu \mathrm{m}$ ). Helium was used as carrier gas, at a flow rate of $1 \mathrm{~mL} / \mathrm{min}$. The injection was performed in splitless mode at $230{ }^{\circ} \mathrm{C}$. Essential oil solution $(1 \mu \mathrm{L})$ in hexane (HPLC Grade) was injected and analyzed with the column held initially at 60 ${ }^{\circ} \mathrm{C}$ for $2 \mathrm{~min}$, and then increased to $260^{\circ} \mathrm{C}$ with a $3{ }^{\circ} \mathrm{C} /$ min heating ramp. Retention indices of all the components were determined by the Kovats method using nalkanes $\left(\mathrm{C}_{6}-\mathrm{C}_{18}\right)$ as standards. The identification of the compounds was based on mass spectra libraries (compared with Wiley and NIST).

\subsection{Statistical analysis \\ 2.4. Statistička analiza}

Statistical Package for the Social Sciences (SPSS) 11.5 software pack was used for all statistical analyses. Independent samples $t$ test and correlation analysis were used. Independent samples $t$ test was separately performed for each variable.

\section{RESULTS AND DISCUSSION} 3. REZULTATI I RASPRAVA

Density of essential oil collected from larvae gallery resin and oleoresin at room temperature was 0.86 $\mathrm{g} / \mathrm{cm}^{3}$. The quantity of turpentine and rosin in the raw material, obtained from larvae gallery resin and oleoresin, is given in Table 1 . The quantity of resin, obtained from oleoresin using the Acid Paste Method, was lower than that of larvae gallery resin. According to the table, for five different trees, considering the quantity of essential oil (turpentine), the mean quantity was $12.82 \%$ in larvae gallery resin and $31.64 \%$ in oleoresin. Considering the quantity of rosin, the mean quantity was $87.18 \%$ in larvae gallery resin and 68.36 $\%$ in oleoresin. There was a difference between the two resin groups in terms of quantity of turpentine and ros- 
... Öz, Deniz, Okan, Fidan: Chemical Composition of Oleoresin and Larvae Gallery Resin...

Table 1 Mean amounts of turpentine and rosin in Pinus brutia Ten. oleoresin and larva gallery resins

Tablica 1. Prosječne količine terpentina i kolofonija u oleorezinu i smoli galerije ličinki od drva bora (Pinus brutia)

\begin{tabular}{|c|c|c|c|c|c|c|c|c|c|}
\hline $\begin{array}{c}\text { Tree No } \\
\text { Broj stabla }\end{array}$ & $\begin{array}{c}\text { Age } \\
\text { Starost }\end{array}$ & $\begin{array}{c}\text { Diameter } \\
\text { Promjer } \\
\mathrm{cm}\end{array}$ & $\begin{array}{c}\text { Height } \\
\text { Visina } \\
\mathrm{m}\end{array}$ & \multicolumn{2}{c|}{$\begin{array}{c}\text { Collected Resin } \\
\text { Prikupljena smola } \\
\mathrm{g}\end{array}$} & \multicolumn{2}{c|}{$\begin{array}{c}\text { Turpentine } \\
\text { Terpentin } \\
\%\end{array}$} & \multicolumn{2}{c|}{$\begin{array}{c}\text { Rosin } \\
\text { Kolofonij } \\
\%\end{array}$} \\
\hline \multicolumn{2}{|l}{} & & & LGR & OR & LGR & OR & LGR & OR \\
\hline 1 & 35 & 30 & 18 & 21.7 & 5.6 & 11.9 & 33.0 & 88.1 & 67.0 \\
\hline 2 & 12 & 18 & 8 & 21.4 & 6.5 & 8.9 & 46.3 & 91.1 & 53.7 \\
\hline 3 & 38 & 35 & 18 & 21.8 & 5.8 & 16.2 & 17.2 & 83.8 & 82.8 \\
\hline 4 & 25 & 22 & 13 & 21.6 & 20.2 & 11.1 & 17.5 & 88.9 & 82.5 \\
\hline 5 & 20 & 15 & 20 & 21.5 & 7.4 & 16.0 & 44.2 & 84.0 & 55.8 \\
\hline \multicolumn{7}{|l|}{} \\
\hline
\end{tabular}

LGR - Larvae gallery resin / smola galerije ličinki, OR - Oleoresin / oleorezin

in. When larvae gallery resin and oleoresin were analyzed with independent two samples $t$ test, a significant difference was found between the quantity of raw material and quantities of turpentine and rosin $(p<0.05)$. However, there was no significant correlation between tree dimensions (age, diameter, height) and quantity of turpentine and rosin $(p>0.05)$.

Components of oleoresin, obtained from five different trees of Pinus brutia, and components of larvae gallery resin of D.sylvestrella Ratz are given in Table 2 . The representative chromatograms of oleoresin and larvea gallery resin of tree No. 2 are given in Figure 4 and 5. Thirty six components were identified in oleoresin, while 39 components were identified in larvae gallery resin. For both, oleoresin and larvae gallery resin, $\alpha$-pinene, $\beta$-pinene and $\gamma$-terpinene were found in the highest quantities among all identified monoterpene components. Amongst all the components of monoterpenoids, which were identified in oleoresin, isopinocampheol, terpinene-4-ol and $\alpha$-terpineol were in the highest quantities. However, for monoterpenoids identified in larvae gallery resin, the highest quantities were recorded for thymol methyl ether, p-menth-1-en-8-ol and terpinene-4-ol in decreasing order. Isopinocamphone, terpinene-4-ol and $\alpha$-terpineol were in the highest quantities and they accounted for $48 \%$ of all components of monoterpenoids, which were identified in oleoresin. However, the highest quantities were recorded for thymol methyl ether, p-menth-1-en-8-ol and terpinene-4-ol and they accounted for $51 \%$ of monoterpenoids identi- fied in larvae gallery resin. Among the sequiterpenes, longifolene, $\beta$-caryophyllene and $\alpha$-humulene provided the highest quantities in oleoresin and they accounted for $27 \%$ of all sesquiterpenes for larvae gallery resin. The highest quantities were found for $\beta$-caryophyllene, $\alpha$-himachalene and longicyclen, respectively, and they accounted for $24 \%$ of all sesquiterpenes.

When Table 2 is taken into consideration, the following components were found in oleoresin, while they could not be identified in larvae gallery resin: $p$-cymene and $\Delta^{2}$-carene (monoterpenes), nopinon, isopinocamphone, carvacrol methyl ether and cuminaldehyde (monoterpenoids) and $\alpha$-amorphen (sesquiterpenes). In contrast, the following components were found in larvae gallery resin, but they could not be identified in oleoresin: myrcene (monoterpenes), thujone2-on, cis-pinocarveol, p-menth-1-en-8-ol, thymol methyl ether and perillal (monoterpenoids), $\gamma$-muurolene (sesquiterpenes) and spathulenol (sesquiterpenoids). Also, according to literature, cortical monoterpene compositions of susceptible varieties tend to be higher in $\Delta^{3}$-carene and terpinolene (Tobolski and Hanover, 1971; Ruby and Wright, 1976). However, our data does not exactly support the hypotheses associating susceptibility of pines attacked by $D$. sylvestrella Ratz with high levels of $\Delta^{3}$-carene and terpinolene in pine oleoresin.

When Figure 6 is examined, quantities of the following components are remarkably lower in larvae gallery resin than in the oleoresin: $\beta$-pinene, limonen, sylvestrene, 1.3.8-p- menthatiren, $\alpha$-terpineol, $\alpha$-longi-

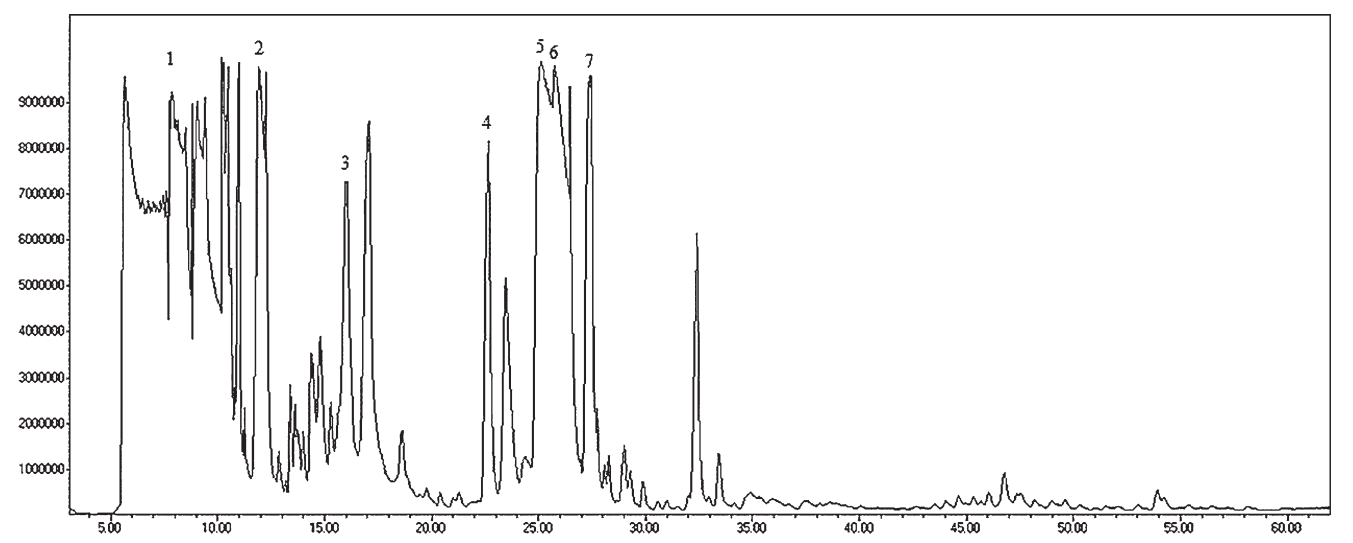

(1) $\beta$-pinene; (2) 1.3.8-p- menthatiren; (3) $\alpha$-terpineol; (4) $\alpha$-longipinene; (5) longifolene; (6) $\alpha$-himachalene; (7) $\alpha$-humulene

Figure 4 GC-MS chromatogram of oleoresin in Pinus brutia for tree No. 2

Slika 4. GC-MS kromatogram oleorezina sa stabla Pinus brutia broj 2 
Öz, Deniz, Okan, Fidan: Chemical Composition of Oleoresin and Larvae Gallery Resin...

Table 2 Identified components in the essential oil of $P$. brutia oleoresin and larvae gallery resin

Tablica 2. Identificirane sastavnice eteričnih ulja oleorezina i smole galerije ličinki dobivenih od bora (Pinus brutia)

\begin{tabular}{|c|c|c|c|c|c|c|c|c|}
\hline \multirow{3}{*}{$\begin{array}{l}\text { Compound } \\
\text { Sastavnica }\end{array}$} & & \multirow{3}{*}{ RI } & \multicolumn{5}{|c|}{ Tree No / Broj stabla } & \multirow{3}{*}{$\begin{array}{c}\text { AVG. } \\
\text { Prosječno } \\
\%\end{array}$} \\
\hline & & & 1 & 2 & 3 & 4 & 5 & \\
\hline & & & \multicolumn{5}{|c|}{$\%$} & \\
\hline \multirow{2}{*}{$\alpha$-Pinene } & LGR & \multirow[t]{2}{*}{940} & 14.7 & 31.1 & 25.8 & 12.1 & 17.3 & 20.2 \\
\hline & OR & & 15.4 & 18.4 & 11.3 & 27.2 & 26.0 & 19.7 \\
\hline \multirow{2}{*}{ Camphene } & LGR & \multirow[t]{2}{*}{956} & 5.9 & 3.0 & 3.8 & - & - & 4.2 \\
\hline & OR & & 10.1 & - & 3.6 & - & 1.3 & 5.0 \\
\hline \multirow{2}{*}{$\beta$-Pinene } & LGR & \multirow[t]{2}{*}{980} & 2.0 & 16.2 & 17.0 & 2.7 & 9.3 & 9.4 \\
\hline & OR & & 7.9 & 14.7 & 11.3 & 21.1 & 11.7 & 13.3 \\
\hline \multirow{2}{*}{ Myrcene } & LGR & \multirow[t]{2}{*}{995} & - & - & 2.2 & - & - & 2.2 \\
\hline & OR & & - & - & - & - & - & - \\
\hline \multirow{2}{*}{$\Delta^{2}$-Carene } & LGR & \multirow[t]{2}{*}{1005} & - & - & - & - & - & - \\
\hline & OR & & - & - & 8.4 & 5.3 & - & 6.9 \\
\hline & LGR & 1025 & 9.1 & - & 0.8 & - & 1.7 & 3.9 \\
\hline Limonene & OR & & 6.2 & - & 6.2 & - & - & 6.2 \\
\hline Sulyestrone & LGR & 1026 & - & - & - & 4.0 & 4.0 & 4.0 \\
\hline Sylvestrene & OR & & - & - & - & - & 7.4 & 7.4 \\
\hline$\Delta^{3}$ Carene & LGR & 1028 & - & 5.5 & 0.7 & - & - & 3.1 \\
\hline$\Delta^{3}$-Carene & OR & & - & 4.7 & - & 2.0 & - & 3.7 \\
\hline R Dinene & LGR & 1039 & 0.4 & - & - & - & - & 0.4 \\
\hline 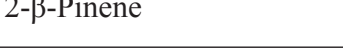 & OR & & - & - & - & - & - & - \\
\hline & LGR & 1053 & 12.7 & 2.2 & 20.2 & 7.0 & 8.6 & 10.1 \\
\hline$\gamma$-Terpinene & OR & & 8.9 & 7.7 & 3.8 & 19.6 & 10.9 & 10.2 \\
\hline & LGR & 1090 & 5.1 & 7.2 & 4.2 & 8.4 & 5.9 & 6.2 \\
\hline Terpinolene & OR & & 3.9 & 6.5 & - & 8.2 & - & 6.2 \\
\hline & LGR & 1096 & - & - & - & - & - & \\
\hline p-Cymene & OR & & - & - & 1.6 & - & - & 1.6 \\
\hline $138-$ Menthatirene & LGR & 1111 & 0.1 & 0.2 & - & 0.2 & 0.4 & 0.2 \\
\hline $1,3,8-p$-Menthatirene & OR & & - & 0.3 & 0.2 & - & - & 0.3 \\
\hline & LGR & 1122 & 0.5 & 0.9 & 0.2 & 1.1 & 1.1 & 0.8 \\
\hline$\alpha$-Campholenal & OR & & 0.8 & 0.4 & 0.7 & - & 0.3 & 0.6 \\
\hline 48 novyn-menth 1 ene & LGR & 1138 & 0.1 & - & - & - & - & 0.1 \\
\hline 4,8-epoxy-p-menth-1-ene & OR & & - & - & - & - & - & - \\
\hline & LGR & 1136 & 0.7 & 0.8 & 0.2 & 1.1 & - & 0.7 \\
\hline trans-Pinocarveol & OR & & 1.2 & 1.1 & 0.5 & - & 0.6 & 0.9 \\
\hline Noninon & LGR & 1144 & - & - & - & - & - & - \\
\hline Nopinon & OR & & - & - & - & - & 0.2 & 0.2 \\
\hline Joninosomubor & LGR & 1176 & - & - & - & - & - & - \\
\hline Isopinocampheol & OR & & - & 4.6 & - & - & - & 4.6 \\
\hline Terninen 4 o & LGR & 1179 & 1.6 & 0.4 & 0.8 & 4.3 & 3.7 & 2.2 \\
\hline Terpinen-4-ol & OR & & - & - & 3.9 & 0.3 & 1.0 & 1.7 \\
\hline cic Dinocaryeol & LGR & 1180 & - & - & - & - & 1.9 & 1.9 \\
\hline cis-Pinocarveol & OR & & - & - & - & - & - & - \\
\hline Thuipen 2 one & LGR & 1238 & 0.2 & - & - & - & - & 0.2 \\
\hline Thujone-2-one & OR & & - & - & - & - & - & - \\
\hline Ternineol $12 \mathrm{~s}$ & LGR & 1189 & 2.6 & 2.4 & 0.9 & - & 0.8 & 1.7 \\
\hline$\alpha$-Terpineol & OR & & 4.3 & 5.0 & 3.1 & 0.4 & 2.2 & 3.0 \\
\hline Murtenol & LGR & 1198 & - & 2.0 & - & - & - & 2.0 \\
\hline Myrtenal & OR & & 0.8 & - & - & - & 0.4 & 0.6 \\
\hline month 1 on $\&$ l & LGR & 1211 & - & - & - & - & 5.0 & 5.0 \\
\hline p-menth-1-en-8-ol & OR & & - & - & - & - & - & - \\
\hline Thymol metbul ether & LGR & 1230 & - & - & - & 5.3 & - & 5.3 \\
\hline Thymol methyl ether & OR & & - & - & - & - & - & - \\
\hline Cuminoldehyde & LGR & 1240 & - & - & - & - & - & - \\
\hline Cumınaldehyde & OR & & - & - & - & - & 0.4 & 0.4 \\
\hline Coruerol mothyl ther & LGR & 1245 & & & & & & \\
\hline Carvacrol methyl ether & OR & & - & - & 0.4 & - & - & 0.4 \\
\hline Perillal & LGR & 1270 & - & - & - & - & 0.7 & 0.7 \\
\hline Perillal & OR & & - & - & - & - & - & - \\
\hline
\end{tabular}


... Öz, Deniz, Okan, Fidan: Chemical Composition of Oleoresin and Larvae Gallery Resin...

\begin{tabular}{|c|c|c|c|c|c|c|c|c|}
\hline \multirow{3}{*}{$\begin{array}{l}\text { Compound } \\
\text { Sastavnica }\end{array}$} & & \multirow{3}{*}{ RI } & \multicolumn{5}{|c|}{ Tree No / Broj stabla } & \multirow{3}{*}{$\begin{array}{c}\text { AVG. } \\
\text { Prosječno } \\
\%\end{array}$} \\
\hline & & & 1 & 2 & 3 & 4 & 5 & \\
\hline & & & \multicolumn{5}{|c|}{$\%$} & \\
\hline \multirow{2}{*}{$\alpha$-Longipinene } & LGR & \multirow[t]{2}{*}{1356} & - & - & - & 0.4 & - & 0.4 \\
\hline & OR & & 2.9 & 2.9 & 3.1 & 0.6 & 2.4 & 2.4 \\
\hline \multirow{2}{*}{ Longicyclen } & LGR & \multirow[t]{2}{*}{1370} & 1.6 & 2.1 & 0.8 & 3.5 & 4.4 & 2.5 \\
\hline & OR & & 1.7 & 2.6 & 1.8 & - & - & 2.0 \\
\hline \multirow{2}{*}{$\beta$-Cubeben } & LGR & \multirow[t]{2}{*}{1390} & 1.0 & 2.0 & 0.6 & 3.6 & 2.6 & 2.0 \\
\hline & OR & & 0.3 & - & - & - & 0.5 & 0.4 \\
\hline \multirow{2}{*}{ Sativen } & LGR & \multirow[t]{2}{*}{1395} & 0.3 & - & - & - & - & 0.3 \\
\hline & OR & & - & - & 0.4 & - & - & 0.4 \\
\hline \multirow{2}{*}{ Longifolene } & LGR & \multirow[t]{2}{*}{1412} & - & - & - & - & 0.7 & 0.7 \\
\hline & OR & & 10.8 & 17.0 & 10.2 & 5.5 & 6.0 & 9.9 \\
\hline \multirow{2}{*}{$\beta$-Caryophyllene } & LGR & \multirow[t]{2}{*}{1421} & 7.0 & 8.2 & 5.6 & 24.4 & 8.5 & 10.8 \\
\hline & OR & & 8.6 & 1.9 & 9.9 & 7.6 & 10.9 & 7.8 \\
\hline \multirow{2}{*}{$\alpha$-Himachalene } & LGR & \multirow[t]{2}{*}{1451} & 8.2 & 9.0 & 9.3 & 2.6 & 7.6 & 7.3 \\
\hline & OR & & - & 0.3 & - & - & 0.6 & 0.5 \\
\hline \multirow{2}{*}{$\alpha$-Humulene } & LGR & \multirow[t]{2}{*}{1456} & 0.1 & - & - & - & 0.7 & 0.4 \\
\hline & OR & & 2.8 & 4.6 & 3.6 & 1.7 & 3.9 & 3.3 \\
\hline \multirow{2}{*}{$\gamma$-Muurolene } & LGR & \multirow[t]{2}{*}{1485} & 2.1 & 2.3 & 1.6 & 6.8 & 3.4 & 3.2 \\
\hline & OR & & - & - & - & - & - & - \\
\hline \multirow{2}{*}{$\gamma$ - Himachalene } & LGR & 1488 & - & 0.4 & - & 0.9 & - & 0.7 \\
\hline & OR & & 0.7 & 0.6 & 0.6 & - & 0.8 & 0.7 \\
\hline & LGR & 1488 & - & - & - & - & - & - \\
\hline$\alpha$-Amorphen & OR & & - & 0.2 & - & - & - & 0.2 \\
\hline Murolan & LGR & 1503 & - & - & - & 0.3 & - & 0.3 \\
\hline$\alpha$ - Murolen & OR & & 0.2 & 0.4 & - & - & 0.2 & 0.3 \\
\hline B Himocholono & LGR & 1505 & 0.2 & 0.2 & - & 0.6 & - & 0.3 \\
\hline B-Himachalene & OR & & - & - & 0.2 & - & - & 0.2 \\
\hline & LGR & 1508 & - & - & - & - & 0.8 & 0.8 \\
\hline$\beta$-Bisabolene & OR & & - & 0.2 & - & - & - & 0.2 \\
\hline A mronbon & LGR & 1515 & - & - & - & 0.4 & 0.2 & 0.3 \\
\hline$\Delta$-Amrophen & OR & & - & 0.1 & - & - & - & 0.1 \\
\hline Snothulanol & LGR & 1573 & 0.5 & - & - & - & 3.4 & 2.0 \\
\hline Spathulenol & OR & & - & - & - & - & - & - \\
\hline Humulo orid & LGR & 1580 & - & - & - & - & 0.3 & 0.3 \\
\hline Humulene epoxide-II & OR & & - & - & 0.3 & - & - & 0.3 \\
\hline Corvonbullon ovide & LGR & 1585 & 1.1 & 1.1 & 0.6 & 4.6 & 1.9 & 1.9 \\
\hline Caryophyllen oxide & OR & & 2.0 & 1.8 & 1.8 & 0.2 & 1.6 & 1.5 \\
\hline & LGR & & 77.8 & 97.2 & 95.3 & 94.3 & 94,9 & 91.15 \\
\hline Total & OR & & 89.5 & 95.9 & 86.9 & 99.7 & 89.3 & 92.26 \\
\hline
\end{tabular}

RI - Retention Index / indeks retencije; LGR - Larvae Gallery Resin / smola galerije ličinki; OR - Oleoresin / oleorezin

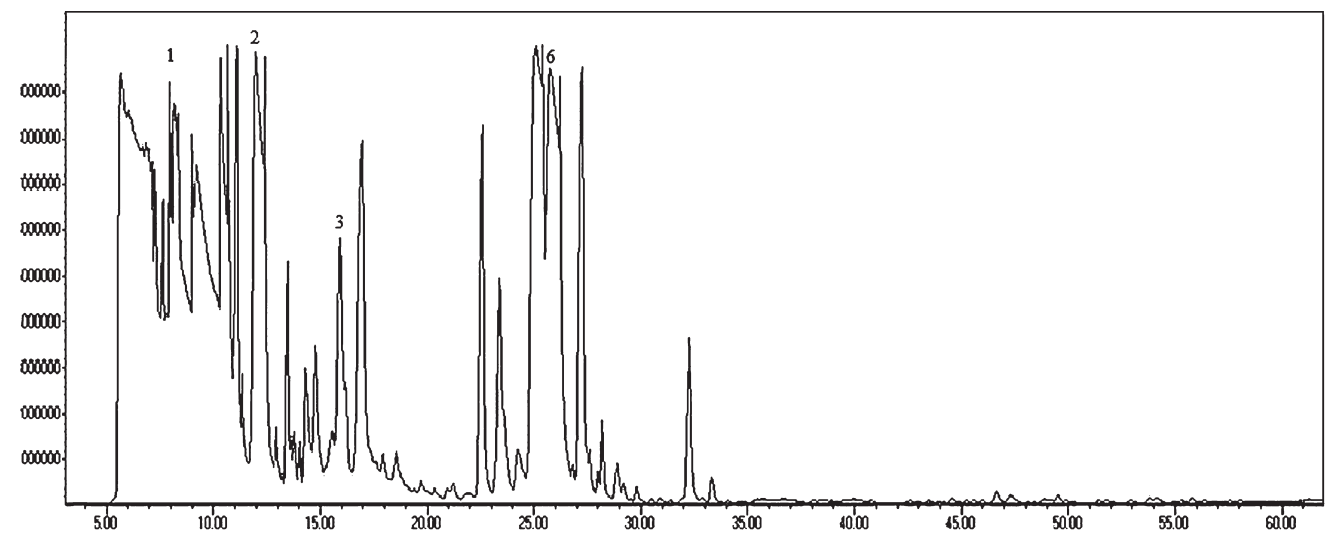

(1) $\beta$-pinene; (2) 1.3.8-p- menthatiren; (3) $\alpha$-terpineol; (6) $\alpha$-himachalene.

Figure 5 GC-MS chromatogram of larvae gallery resin in Pinus brutia for tree No. 2

Slika 5. GC-MS kromatogram smole galerije ličinki sa stabla Pinus brutia broj 2 


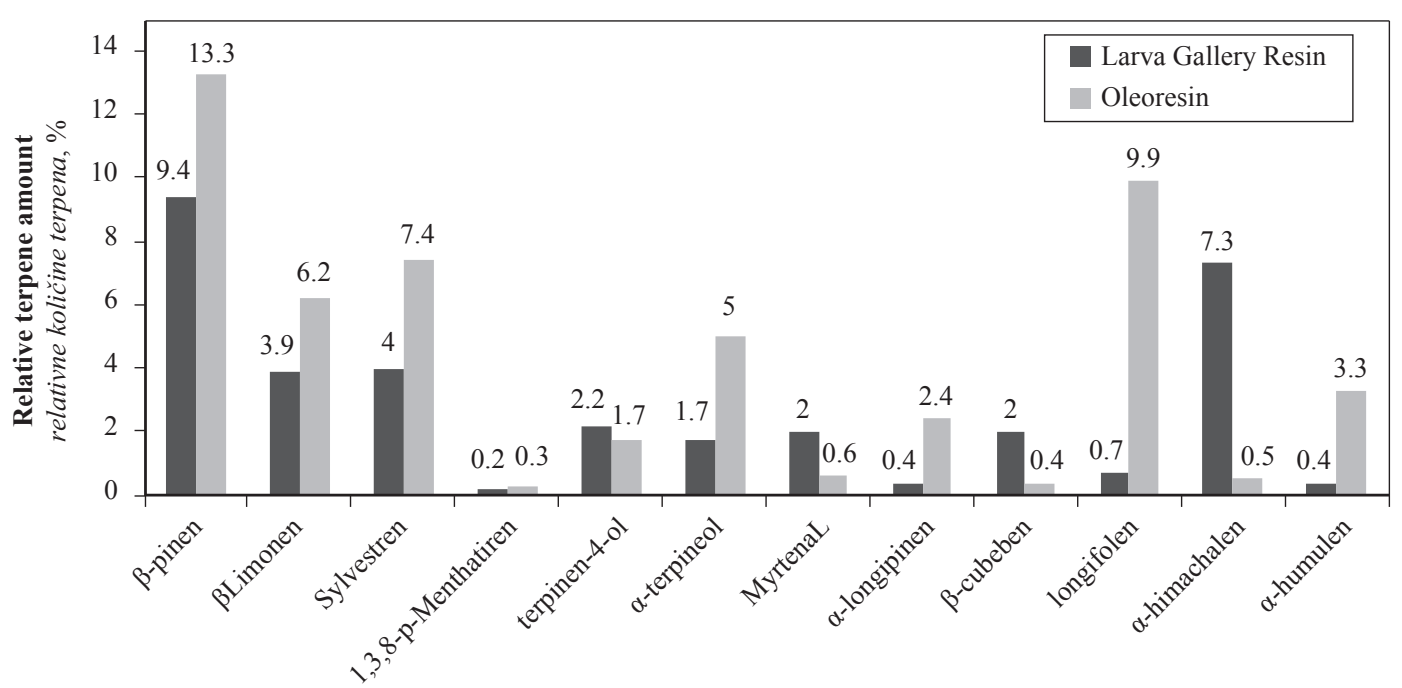

Figure 6 Comparison between chemical compositions (relative terpene amount - \%) of larvae gallery resin and Pinus brutia oleoresin

Slika 6. Usporedba kemijskog sastava smole (relativne količine terpena - \%) galerije ličinki i oleorezina od stabla bora Pinus brutia

pinene, longifolene and $\alpha$-humulene. Terpinen-4-ol, $\beta$-cubebene, myrtenal, and $\alpha$-himachalene were found in higher quantities in larvae gallery resin than in the oleoresin. Based on statistical analysis with $t$ test only, significant differencea were found between sylvestrene, myrtenal, $\alpha$-longipinene, longifolene, $\alpha$-himachalene and $\alpha$-humulene $(p<0.05)$.

Table 3 shows quantities of terpenes for larvae gallery resin and oleoresin. According to the table, the quantity of monoterpenes identified in oleoresin was generally higher in comparison with the larvae gallery resin except for tree No. 2 and 3. Quantities of all other monoterpenoids, sesquiterpenes and sesquiterpenoids were generally lower in larvae gallery resins except for tree No. 4 and 5. However, when statistical analysis was made with the $\mathrm{T}$ test, no significant differences were found between monoterpenes and monoterpeneoids. No significant differences were either found between sesquiterpenes and sesquiterpenoids ( $p>0.05$ ).

The following compounds are found in turpentine of Dioryctria sylvestrella Ratz's larvae gallery resin, while they are not found in turpentine of oleoresin: 2 - $\beta$-pinene $(0.4 \%)$, myrcen $(2.2 \%), 4,8$-epoxyp-menth-1-en $(0.1 \%)$, thujone-2-on $(0.2 \%)$, cis-pinocarveol (1.9\%), p-menth-1-en-8-ol (5.0\%), thymol methyl ether (5.3\%), perillal (0.7\%), spathulenol (2.0 $\%)$ and $\gamma$-muurolene (3.2 percent). In comparison with larvae gallery resins of Dioryctria sylvestrella Ratz, the following compounds are found only in oleoresin: $p$ cymene $(1.6 \%), \Delta^{2}$-carene $(6.9 \%)$, nopinon $(0.2 \%)$, isopinocamphone (4.6\%), carvacrol methyl ether (0.4 $\%)$, cuminal $(0.4 \%)$ and $\alpha$-amorphen $(0.2 \%)$.

In the present study, the quantity of oleoresin was far lower than the quantity of larvae gallery resin. However, the quantity of turpentine obtained from oleoresin is considerably higher than larvae gallery resin. It is reported in previous studies that the underlying reason originates from the difference between the release times of resin samples (Deniz et al., 2006). The difference between quantities of turpentine obtained from Pinus bruita using the Acid-Paste Method can be secondary to the difference between the genetic features of trees (Gül, 1999). Another prominent finding is that there is no correlation between the dimensions of tree (diameter, age, height) and quantity of turpentine and rosin in oleoresin. This finding is consistent with results of previous studies (Kleinhentz et al., 1999).

Quantities of essential oil components, which were identified in the oleoresin of Pinus brutia, are largely in concordance with the literature; there are, however, some qualitative differences (Acar, 1988; Gül, 1999; Gören et al., 2010). Previous studies report that genetic features and ecological conditions may quantitatively and qualitatively change the resin com-

Table 3 The main terpene-class quantities in P. brutia Ten. oleoresin and larvae gallery resin

Tablica 3. Količine glavnih terpena u oleorezinu i smoli galerije ličinki od stabla bora Pinus brutia

\begin{tabular}{|c|c|c|c|c|c|c|c|c|}
\hline \multirow{2}{*}{$\begin{array}{c}\text { Tree No. } \\
\text { Broj stabla }\end{array}$} & \multicolumn{2}{|c|}{$\begin{array}{c}\text { Monoterpenes } \\
\text { Monoterpeni } \\
\text { \% }\end{array}$} & \multicolumn{2}{c|}{$\begin{array}{c}\text { Monoterpenoids } \\
\text { Monoterpenoidi } \\
\text { \% }\end{array}$} & \multicolumn{2}{c|}{$\begin{array}{c}\text { Sesquiterpenes } \\
\text { Seskviterpeni } \\
\%\end{array}$} & \multicolumn{2}{c|}{$\begin{array}{c}\text { Sesquiterpenoids } \\
\text { Seskviterpenoidi } \\
\%\end{array}$} \\
\cline { 2 - 10 } & LGR & OR & LGR & OR & LGR & OR & LGR & OR \\
\hline 1 & 50.0 & 52.4 & 5.6 & 7.1 & 20.5 & 28.0 & 1.6 & 2.0 \\
\hline 2 & 65.4 & 52.3 & 6.5 & 11.1 & 24.2 & 30.8 & 1.1 & 1.8 \\
\hline 3 & 74.7 & 46.4 & 2.1 & 8.6 & 17.9 & 29.8 & 0.6 & 2.1 \\
\hline 4 & 34.4 & 83.4 & 11.8 & 0.7 & 43.5 & 15.4 & 4.6 & 1.0 \\
\hline 5 & 47.2 & 57.3 & 13.6 & 5.1 & 28.9 & 25.3 & 5.6 & 1.6 \\
\hline Avg. & 54.34 & 58.36 & 7.92 & 6.52 & 27.0 & 25.86 & 2.7 & 1.7 \\
\hline
\end{tabular}


ponents of trees (Gül, 1999; Dob et al., 2005; Gören et al., 2010). For instance, in Izmir, Acar (1988) reported that $\alpha$-pinene, $\beta$-pinene $\Delta^{3}$-carene and camphene in $\mathrm{Pi}$ nus brutia oleoresin was $78 \%, 13 \%, 4 \%, 0.9 \%$, respectively. However, Gül et al. (1999) documented that $\alpha$-pinene, $\beta$-pinene $\Delta^{3}$-carene and camphene in Pinus brutia oleoresin, located in the same region as Acar's findings, were $50 \%, 29 \%, 14 \%, 1.2 \%$, respectively. In the analysis of oleoresin of Pinus brutia found in Greece, the reported rates were $13.7 \%, 5.1 \%, 0.5 \%$ and $0.4 \%$, respectively, for $\alpha$-pinene, $\beta$-pinene, $\alpha$-myrcene and limonene. However, $\Delta^{3}$-carene could not be found (Papajannopoulos et al., 2001).

Previous studies also reported some qualitative and quantitative changes in the chemical composition of resins of trees, where Dioryctria sylvestrella Ratz is hosted (Kleinhentz et al., 1999; Mumm et al., 2003; Mumm et al., 2004). In the present study, $\alpha$-pinene is found in the highest amounts in Pinus bruita oleoresin and larvae gallery resin. This finding is consistent with the results of a previous study conducted on Pinus sylvestris (Kleinhentz et al., 1999). In larvae gallery resin, another monoterpenes compound, $\Delta^{3}$-carene, was found in low quantities. No change was observed in the quantity of terpinolen. In previous studies, it was reported that in samples of Dioryctria zimmermani, the quantity of $\Delta^{3}$-carene and terpinolene components was high (Tobolski and Hanover, 1971; Wright et al., 1975; Ruby and Wright, 1976). However, in a similar study conducted by different researchers, low quantities of $\Delta^{3}$-carene and terpinolene were reported in the resin components (Sadof and Grant, 1997). In another study, monoterpenes components of resins of Pinus pinaster, which was attacked by D.sylvestrella, were examined and it was found that the quantity of terpinolene was undoubtedly high, but the component of $\Delta^{3}$-carene could not be identified in larvae and oleoresin (Kleinhentz et al., 1999).

Amongst the components of larvae gallery resin, myrcene was exclusively identified. It was also apparent that the quantity of $\beta$-caryophyllene components was high, while the quantities of limonen, longifolene and camphene were low. A study was conducted on the examination of resin components following an attack of D. sylvestrella on Pinus pinaster, and it was found that excluding the change in the quantity of limonene, the changes in quantities of other resin components were consistent with that of our study (Kleinhentz et al., 1999). However, in another study examining resin components of Pinus sylvestris attacked by Diprion pini, the changes in quantity of limonene were consistent with values obtained in the present study (Mumm et al., 2003). It was reported that due to toxic effects, limonene is found in high quantities in trees belonging to the Abies, Picea and Pinus species and attacked by various insects (Norlander, 1990; Sadof and Grant, 1997). However, limonene can be easily transformed into other compounds, such as $\alpha$-terpineol and cis-carveol, via biotransformation under the effect of various microorganisms (Henriksson et al., 2004; Noma and Asakawa, 2010). In the present study, the quantity of limonene was low in the larvae gallery resin of Pinus brutia in comparison with oleoresin.
In the present study, myrtenal, a monoterpenoid component, was found in low quantities in oleoresin; the quantity was high in larvae gallery resin. Mumm et al. (2004) reported similar results in a study which was conducted on Pinus nigra attacked by Diprion pini. $\beta$-caryophyllen, a sesquiterpenes, was also found at high rates in larvae gallery resin. Various studies have reported that following ovulation (egg laying) of various insects, the quantity of $\beta$-farnesene dramatically increases oleoresin (Mumm and Hilker, 2006; Köpke, 2010). The higher quantity of $\beta$-farnesene in trees, which were exposed to ovulation, is considered as a defence mechanism that attracts egg parasites to the tree. However, $\beta$-farnesene alone is not sufficient to attract egg parasites. Two other important components, which are required to attract egg parasites, are $\beta$-caryophyllene and $\alpha$-humulene (Beyaert et al., 2010). In addition, studies report that $\beta$-farnesene is synthesized primarily for producing $\beta$-caryophyllen (Köpke, 2010).

In comparison with quantities recorded in oleoresin, the quantity of monoterpenoids (oxidized monoterpenes), sesquiterpenes and sesquiterpenoid components is higher in larvae gallery resin, while the quantity of monoterpenes is decreased. As studies suggest, the interactions between bark beetles, their associated fungi and the host tree phloem produce oxygenated monoterpenes. In addition, previous studies reported that sesquiterpenes are found at higher rates in trees which are attacked by insects (Mumm et al., 2003; Köpke, 2010).

\section{CONCLUSIONS}

\section{ZAKLJUČAK}

In the current study, no significant qualitative difference was found between the larvae gallery resin and oleoresin of Dioryctria sylvestrella Ratz. in terms of terpene components. The changes identified in both larvae gallery resins and oleoresins are largely consistent with the literature. In addition, ecological conditions and tree genetics may change the chemical composition of oleoresin.

\section{REFERENCES}

5. LITERATURA

1. Acar, M. İ., 1988: Chemical composition of Redpine (Pinus brutia). Ankara, Turkey: Forest Research Institute Press, 3 (1): 35-47.

2. Batur, M.; Kiracioglu, Ö.; Akkaya, M., 2008: The Effects of Acid-Paste Method on Volume Increment and Product Distribution in Resin Production. Ministry of Environment and Forestry, Ege Forestry Research Institute, Technical bulletin: 37, İzmir, Turkiye, pp.1-36.

3. Beyaert, I.; Wäschke, N.; Scholz, A.; Varama, M.; Reinecke, A.; Hilker, M., 2010: Relevance of resource-indicating key volatiles and habitat odour for insect orientation. Animal Behav., 79: 1077-1086. http://dx.doi.org/10.1016/j.anbehav.2010.02.001.

4. Bonello, P.; Gordon, T. R.; Herms D. A.; Wood D. L.; Erbilgin, N., 2006: Natural and ecological implications of pathogen-induced systemic resistance in conifers: A 
novel hyppthesis. Physiol and Molec Plant Path, 68: 95104. http://dx.doi.org/10.1016/j.pmpp.2006.12.002

5. Coppen, J. J. W.; Hone, G. A., 1995: Gum naval stores: turpentine and rosin from pine resin. Rome, Food and Agriculture Organization of United Nations (FAO) Press, pp.17-23.

6. De Moraes, C. M.; Lewis, W. J.; Parè, P. W.; Alborn, H. T.; Tumlinson, J. H., 1998: Herbivore infested plants selectively attract parasitoids. Nature, 393: 570-573. http://dx.doi.org/10.1038/31219

7. Deniz, I, 2002: The biosynthesis of the resin and the gumrosin production. Kastamonu Educat J, 10: 375-386.

8. Deniz, İ.; Eroğlu, M.; Yaşar, A.; Öz, M.; Şahin, H. İ., 2006: Reçine kelebeği (Dioryctria sylvestrella) tahribatıyla oluşan kızılçam reçinesinin uçucu bileşenleri. Proceeding of I. International Non-Wood Forest Product, 1-4 November 2006; Trabzon, Turkey, pp. 147-148.

9. Dığrak, M.; Ilçim A.; Alma, M. H., 1999: Antimicrobial activities of several parts of Pinus brutia, Juniperus oxycedrus, Abies cilicia, Cedrus libani and Pinus nigra. Phytother Res, 13: $\quad 584-587 . \quad h t t p: / / d x . d o i . o r g / 10.1002 /(S I C I) 1099-$ 1573(199911)13:7<584::AID-PTR508>3.0.CO;2-S

10. Dob, T.; Berramdane, T.; Chelgoum, C., 2005: Chemical composition of essential oil of Pinus halepensis Miller growing in Algeria. C. R. Chimie, 8: 1939-1945. http://dx.doi.org/10.1016/j.crci.2005.05.007

11. Gören, A. C.; Bilsel, G.; Öztürk, A. H.; Topçu, G., 2010 : Chemical composition of natural colophony from pinus brutia and comparisons with synthetic colophony. Nat Prod Commun, 5: 1729-1732.

12. Gül, S., 1999: Studies on the composions of gum and sulphate turpenties produced in Turkey and the production of some new commercial products. Ege Forestry Research Institute, Izmir-Turkey.

13. Henriksson, M. L.; Isaksson, D.; Vanèk, T.; Valterová, I.; Högberg, H. E.; Sjödin, K., 2004: Transformation of terpenes using a Picea abies suspension culture. J. of Biotechnol., 107: 173-184. http://dx.doi.org /10.1016/j.jbiotec.2003.10.009.

14. Jactel, H.; Kleinhentz, M.; Bezard, A. M; Poll, M. F.; Menassieu, P; Burban, C., 1996: Terpene variations in maritime pine constitutive oleoresin related to host tree selection by Dioryctria sylvestrella RATZ. (Lepidoptera: Pyralidae). J. Chem. Ecol., 22 (5): 1037-1050. http://dx.doi.org/10.1007/BF02029953

15. Kanat, M.; Sivrikaya, F., 2004: The effects of chemical control against pine processionary moth, Thaumetopoea pityocampa (Schiff.) on diameter increment in Pinus brutia (Ten.) trees in Kahramanmaraş region. KSU J. Sci. and Eng., 7 (2): 60-64.

16. Kleinhentz, M.; Jactel, H.; Mensassieu, P., 1999: Terpene attractant candidates of Dioryctria sylvestrella in maritime pine (Pinus pinaster) oleoresin, needles, liber and headspace samples. J. Chem. Ecohol., 25 (12): 2741-2756. http://dx.doi.org/10.1023/A:1020803608406

17. Köpke, D., 2010: Molecular Characterization of Pine Response to Insect Egg Deposition. PhD, Pharmazie der Freien Universität, Berlin, Germany.

18. Mumm, R.; Schrank, K.; Wegener, R.; Schulz, S.; Hilker, M., 2003: Chemical analysis of volatiles emitted by $P i$ nus sylvestris after induction by insect oviposition. J. Chem. Ecol., 29 (5): 1235-1252. http://dx.doi.org/10.1023/A:1023841909199

19. Mumm, R.; Tiemann, T.; Schulz, S.; Hilker, M., 2004: Analysis of volatiles from black pine (Pinus nigra): significance of wounding and egg deposition by a herbivorous sawfly. Phytochem, 65: 3221-3230. http://dx.doi.org/10.1016/j.phytochem.2004.10.010
20. Mumm, R.; Hilker, M., 2006: Direct and indirect chemical defence of pine against folivorous insects. Trends in Plant Scien, 11 (7): 351-358.

http://dx.doi.org/10.1016/j.tplants.2006.05.007

21. Noma, Y.; Yoshinori, A., 2010: Biotransformation of monoterpenoids by microorganisms, insects and mammals. Başer, K. H. C. and Buchbauer, G. Jr. (Ed.): Essential Oil. Newyork, USA: CRC Press, pp. 585-726.

22. Norlander, G., 1990: Limonene inhibits attraction to $\alpha$-pinenee in the pine weevils Hylobies abietis and H. pinastri. J. Chem. Ecol., 16 (4): 1307-1320. http://dx.doi.org/10.1007/BF01021028

23. Paine, T. D.; Radda, K. F.; Harrington, T. C., 1997: Interaction among scolytid bark beetles, their associated fungi and live host conifers. Annu. Rev. Entomol., 42: 179206. http://dx.doi.org/10.1146/annurev.ento.42.1.179

24. Papajannopoulos, A. D.; Song, Z. Q.; Liang, Z. Q.; Spanos, J. A., 2001: GC-MS analysis of oleoresin of three Greek pine species. Holz als Roh- Werkstoff, 59: 443446. http://dx.doi.org/10.1007/s00107-001-0249-x

25. Ruby, J. L.; Wright, J. W., 1976: A revised classification of geographic varieties in Scotch pine. Silvae Genet., 25: 169-175.

26. Şensöz, S.; 2003. Slow pyrolysis of wood barks from Pinus brutia Ten. and product compositions. Bioresourc. Tecnohol., 89: 307-311.

http://dx.doi.org/10.1016/S0960-8524(03)00059-2.

27. Sezik, E.; Üstün, O.; Demirci, B.; Başer, K. H. C., 2010: Composition of the essential oils of Pinus nigra Arnold from Turkey. Turk. J. Chem., 34: 313-325. http://dx.doi.org/10.3906/kim-0903-39

28. Tobolski, J. J.; Hanover, J. W., 1971: Genetic variation of the monoterpenes of Scotch pine. For. Sci., 17: 293-299.

29. Trapp, S.; Croteau, R., 2001: Defensive resin biosynthesis in conifers. Annu Rev Plant Physiol Plant Mol Biol, 52: $589-724$.

http://dx.doi.org/10.1146/annurev.arplant.52.1.689

30. Tümen, İ.; Reunanen, M., 2010: A comparative study on turpentine oils of oleoresins of Pinus sylvestris L. from three districts of Denizli. Rec. Nat. Prod., 4: 224-229.

31. Wang, Z.; Calderon, M. M.; Carandang, M. G., 2006: Effects of resin tapping on optimal rotation age of pine plantation. J Forest Eco, 11: 245-260. http://dx.doi.org/10.1016/j.jfe.2005.10.001

32. Wright, J. W.; Wilson, L. F.; Bright, J. N., 1975: Genetic variation in resistance of Scotch pine to Zimmerman pine moth. Great Lakes Entomol., 8: 231-236.

33. Zulak, G. K.; Bolhmann, J., 2010: Terpenoid biosynthesis and specialized vascular cells of conifer defense. J. Integr. Plant Biol., 52 (1): 86-97. http://dx.doi.org/10.1111/j.1744-909.2010.00910.x

34. *** 2013: Ormanların korunması. In: Ormancilik ve Su Şuras1, 21-23 March 2013, Ankara, pp. 1-27.

\section{Corresponding address:}

\section{Lecturer MEHMET OZ}

Department of Forestry

Vocational School of Higher Education

Gumushane University

29000 Gumushane, TURKEY

e-mail:mehmetoz@gumushane.edu.tr 